\title{
Eagle's syndrome: an unusual cause of recurrent neck pain in a child
}

\author{
Arun Kumar, ${ }^{1}$ Indar Kumar Sharawat (10), ${ }^{2,3}$ Lesa Dawman (1) ${ }^{3}$
}

${ }^{1}$ Oral Health Sciences, Post Graduate Institute of Medical Education and Research, Chandigarh, India

${ }^{2}$ Pediatrics, All India Institute of Medical Sciences, Rishikesh, India

${ }^{3}$ Pediatrics, Post Graduate Institute of Medical Education and Research, Chandigarh, India

\section{Correspondence to}

Dr Indar Kumar Sharawat; sherawatdrindar@gmail.com

Accepted 20 January 2020

\section{DESCRIPTION}

A 14-year-old girl presented with recurrent episodes of pain over the right side of the neck for the past 1 year. It was over the upper neck, dull aching, moderate in intensity $(6-7 / 10$ on the pain scale) and radiating to the ipsilateral lower jaw, ear and face. There were 2-3 episodes/day and each episode lasted for 10-15 min. It occasionally aggravates on taking solid food and turning the head towards the left side. She underwent bilateral tonsillectomy one and a half months back and her symptoms had aggravated following the procedure. On examination of the head and neck, no external abnormality was seen. Palpation elicited pain over the right submandibular area anterior to the sternocleidomastoid muscle and intraorally in right retromolar trigone region and peritonsillar fossa. X-ray (figure 1) and CT head (figure 2) showed a bilaterally elongated styloid process, confirmed the diagnosis of Eagle's syndrome (ES). Child was planned for the surgery, but parents were not ready for the procedure. She was started on oral amitriptyline $(25 \mathrm{mg} /$ day $)$ and intermittent analgesics. At 3 months follow-up, she had partial improvement in her symptoms (both intensity and frequency of the episodes was decreased).

ES is a rare condition secondary to elongated ossified styloid process and was described by Eagle in 1937. ${ }^{1}$ Females of third to fourth decades are more commonly affected and only five patients have been reported in children so far. ${ }^{2}$ The accepted length of the styloid process is $2.5 \mathrm{~cm}$ and greater length is considered abnormal. While styloid abnormalities often occur bilaterally but pain symptoms usually present unilaterally. ${ }^{3}$ Pain is the most common presenting symptom of ES and is often unilateral, on the side of the elongated styloid process. Sometimes it radiates to the ipsilateral ear and jaw and present as otalgia or temporomandibular joint pain and may aggravate with yawning and head-turning. Other symptoms are dysphagia/odynophagia, voice changes and foreign body sensation. A patient may

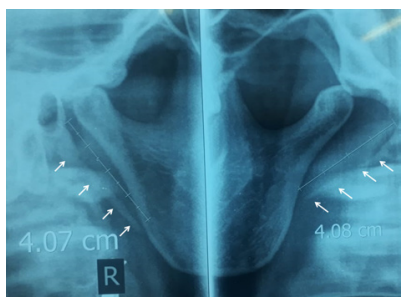

Figure 1 X-ray face. Lateral oblique view of ramus of mandible depicting bilaterally elongated styloid process (right side: $4.07 \mathrm{~cm}$; left side: $4.08 \mathrm{~cm}$ ) (arrow).

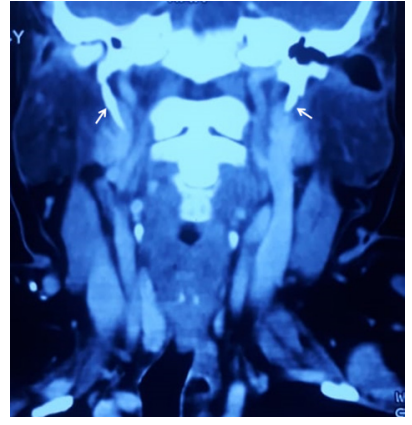

Figure 2 CT scan of the neck coronal view of CT scan showing bilateral elongated styloid process (arrow).

experience visual disturbance, syncope, ischaemic stroke and rarely Horner syndrome due to carotid artery compression. ${ }^{4}$ Presence of an elongated styloid process alone or the pain syndrome alone, are not consistent with the diagnosis of ES and both an elongated styloid process and an appropriate clinical picture is required.

Eagle ${ }^{5}$ divided ES into two subtypes: classical ES and stylocarotid syndrome. Classical ES presents with pain, dysphagia and a foreign body sensation that presents immediately after tonsillectomy while pain, visual disturbance and syncope due to carotid artery compression are the features of stylocarotid syndrome. However, further studies showed that it can occur without tonsillectomy. ${ }^{3}$

The aetiology and pathogenesis of ES are still controversial. Trauma to styloid process, retained embryological cartilage tissue from Reichert's cartilage, calcification of the stylomandibular ligament and expansion of osseous tissue at the origin of the stylomandibular ligament are the proposed theories. ${ }^{6}$ Neuralgia of sphenopalatine ganglia, submandibular sialolithiasis/sialadenitis, glossopharyngeal and trigeminal neuralgia, chronic tonsillopharyngitis, hyoid bursitis, dental pain, cluster type headache, migraine, external otitis, mastoiditis, temporal arteritis, temporomandibular arthritis, cervical vertebral arthritis and neoplasms are the differentials of ES. ${ }^{47}$

Conservative management of ES includes analgesics and a combination of anticonvulsants, antidepressants, local anaesthetic/steroid injections. Literature tends to support surgical treatment as a more definite treatment with long-lasting symptomatic relief. Surgical treatment includes resection of the elongated styloid process via an intraoral or cervical approach. To conclude, ES is very rare in the paediatric population, but it 
should be kept in the differential diagnosis of recurrent neck and cranial pain.

\section{Learning points}

- Eagle's syndrome (ES) is a rare condition secondary to elongated ossified styloid process and neck pain is the most common presenting symptom.

- It is a rare case of recurrent neck pain in children and only five patients have been reported so far.

- Glossopharyngeal and trigeminal neuralgia, submandibular sialolithiasis, sialadenitis, hyoid bursitis, otitis media, temporal arteritis and temporomandibular arthritis are the differentials of ES.

Contributors AK: patient management, literature review and initial draft manuscript preparation. IKS: patient management, critical review of the manuscript for important intellectual content and final approval of the version to be published. LD: literature review, critical review of the manuscript for important intellectual content and final approval of the version to be published.

Funding The authors have not declared a specific grant for this research from any funding agency in the public, commercial or not-for-profit sectors.
Competing interests None declared.

Patient consent for publication Parental/guardian consent obtained.

Provenance and peer review Not commissioned; externally peer reviewed.

\section{ORCID iDs}

Indar Kumar Sharawat http://orcid.org/0000-0002-7003-7218

Lesa Dawman http://orcid.org/0000-0003-4253-3385

\section{REFERENCES}

1 Eagle WW. Elongated styloid processes: report of two cases. Arch Otolaryngol 1937:25:584-7.

2 Gárriz-Luis M, Irimia P, Alcalde J, et al. Stylohyoid complex (Eagle) syndrome starting in a 9-year-old boy. Neuropediatrics 2017;48:053-6.

3 Monsour PA, Young WG. Variability of the styloid process and stylohyoid ligament in panoramic radiographs. Oral Surg Oral Med Oral Pathol 1986;61:522-6.

4 Badhey A, Jategaonkar A, Anglin Kovacs AJ, et al. Eagle syndrome: a comprehensive review. Clin Neurol Neurosurg 2017;159:34-8.

5 Eagle WW. Elongated styloid process: symptoms and treatment. Arch Otolaryngol 1958;67:172-6.

6 Kim E, Hansen K, Frizzi J. Eagle syndrome: case report and review of the literature. Ear Nose Throat J 2008;87:631-3.

7 Freni F, Galletti B, Bruno B, et al. Multidisciplinary approach in the removal of post-trauma foreign bodies in the head and neck district: cases report and review of literature. Acta Medica Mediterranea 2019;35:405-10.

Copyright 2020 BMJ Publishing Group. All rights reserved. For permission to reuse any of this content visit https://www.bmj.com/company/products-services/rights-and-licensing/permissions/

BMJ Case Report Fellows may re-use this article for personal use and teaching without any further permission.

Become a Fellow of BMJ Case Reports today and you can:

- Submit as many cases as you like

- Enjoy fast sympathetic peer review and rapid publication of accepted articles

- Access all the published articles

- Re-use any of the published material for personal use and teaching without further permission

Customer Service

If you have any further queries about your subscription, please contact our customer services team on +44 (0) 2071111105 or via email at support@bmj.com.

Visit casereports.bmj.com for more articles like this and to become a Fellow 